\title{
The Influence of Director Ownership on the Relationship between Firm's Financial Performances (FP) and Social Performance (SP): Malaysian Evidence
}

\author{
Sarifah Ismail $^{\mathrm{a}, 1}$, Teh suhaila Tajuddin ${ }^{\mathrm{b}, 2}$, Zainab Aman ${ }^{\mathrm{c}, 3}$ \\ ${ }^{a}$ Kolej Universiti Islam Antarabangsa Selangor (KUIS), 43000 Kajang Selangor, Malaysia \\ ${ }^{\mathrm{b}}$ Kolej Universiti Islam Antarabangsa Selangor (KUIS), 43000 Kajang Selangor, Malaysia \\ ${ }^{c}$ Kolej Universiti Islam Antarabangsa Selangor (KUIS), 43000 Kajang Selangor, Malaysia \\ ${ }^{1}$ sarifah@kuis.edu.my, ${ }^{2}$ tehsuhaila@kuis.edu.my, ${ }^{3}$ zainab@kuis.edu.my
}

\begin{abstract}
The slack resource theory is argued that companies who are financially strong would have slack resources that would provide the opportunity to invest in social activities for community, employee, and environment. If slack resources are available from previous financial performance, better financial performance would be a predictor for better social performance. However, past studies have documented inconsistent evidence of the relationship between with financial performance (FP) and social performance (SP). To improve the theoretical framework, this study introduces moderator variables, director ownership that expected to enhance the relationship between financial and social performance. This argument is on their ability of influencing company decision making since they are the owner of company. They have voting right to make decision this will help to the increase of slack resources allocation in social activity. Past study documented positive relationship between director ownership and social performance this provide evidence that when director of company have positive view toward SP this will help to increase to allocation available slack resources in social activity that will lead better SP. Sample of this study comprises of 262 public listed companies in Bursa Malaysia for the year 2012. The results of the regression analysis provide a support for slack resource theory, that is, financially strong companies have a positive and significant relationship with social performance. Furthermore this study is expected to supports the board ownership in influencing the relationship. This study contributes new knowledge by introducing director ownership as moderator of the relationship between social performance and financial performance.
\end{abstract}

Keywords: financial performance, social performance, director ownership, slack resources, GRI

\section{Introduction}

Companies are expected to be more responsible in doing business due to the increase of awareness in Corporate Social Responsibilities (CSR) by stakeholder. This awareness emerged after a series of outbreak event by companies throughout the world. The series of event including lacking of corporate governance practices in Enron case 2001, China's Sanlu melamine milk poisoning in 2008, Coco - cola bottle pollution in India and problem of mixing the non halal item in their product by QSR company. These examples create more awareness to stakeholder in demanding good CSR practice by companies. Hence, the companies should be good corporate citizen by taking into consideration the effect of the business operation to various stakeholders. If CSR, is not seriously considered in companies not only stakeholder will suffer but the companies reputations and performance might be affected. For example in China Sanlu case the company suffered losses and nearly declared bankrupt because of having debts total more than 700 million yuan due to unethical business practices (CSR International). Therefore, CSR, it is important because it helps to improve reputation risk, help to manage the risk of loss, attract investor, improve relation with stakeholders, becomes more competitive in mature market, increase employee morale and gaining more brand awareness by potential 
customer. According to CSR Branding survey 2010, $75 \%$ of customer that read good practices in the company website is more likely to purchase company's products or services in future (Star, March 2011).

CSR is also seen as an important corporate strategy in companies. According to survey done by Economist Intelligence Unit 2007, nearly 30\% of global executives consider CSR as the highest priority issue in organization (Choi et al. 2010). So companies are expected to engage in CSR activities that lead to a better Corporate Social Performance (CSP) . CSP is defined as a business organization's configuration of principles of social responsibility, process of social responsiveness, and policies, programs, and observable outcomes as they relate to the firm's societal Relationship (Wood 1991). CSP reports on firm's financial performance from a variety of perspectives including such community involvement, employee relations, product safety, philanthropy and impact of the firm on the environment (Dunn \& Sainty 2009).

CSP is believed to have positive impact on financial performance (FP), this stream of believed argued that CSP and FP is positively correlated because CSP play a role in attracting, retaining and motivating employees thereby increasing productivity and enhancing profitability, enhance revenues by supporting attempts to differentiate the firm's product or services thereby attracting socially conscious consumer and attract resources from socially responsive investors (Moskowitz, 1972; Hillman \& Keim 2001). In order to get benefit from CSP, companies should firstly engage in CSR. Available fund is argued to be important factors to influence the level of companies CSP, especially in developing countries. As compared to developed countries, level of CSP for developing countries is at beginning stage and CSP is not considered as one of business strategy to enhance financial performance as practiced by companies in developed countries. Moreover a CSP in developing countries is expected to be different form developed country because of different economic, social and cultural conditions. Jones (1999) highlights the important of the national socio-culture environment and level of national economic development as important variables influencing CSP understanding and practices. So it is important to examine the level CSP in developing countries and its relationship with financial performance. Since CSR activities have seen as cost incurred program, for example investment in environmental pollution equipment, it is important to identify whether the strong financial performance lead to better CSP in developing countries. It is true financial performance become important determinant of CSP in developing countries.

Previous study done based on slack resources theory (Waddock \& Graves 1997, Preston O’Bannon 1997, Fauzi \& Idris , 2009) find out positive relationship between FP and CSP. Available fund derived from profit of the company is said to be important factor influence CSP. Furthermore, an important issue to be addressed here is the allocation of scare financial resources by the companies. Not necessary by having the extra fund company will invest in CSP unless top management and shareholder of companies is aware the important of CSP for their companies, hence they will influence some portion of available fund in CSP. Normally the decision is done by top management and shareholder of the companies. However to date, there is no documented evidence on the director ownership influences on the allocation of available fund to engage in CSR.

Social performance is defined as the outcome of implementing corporate social responsibilities $(\mathrm{SR})^{1}$ activities and behaviours. It comprises principles of social responsibility, processes of social responsiveness, policies, programs, and observable outcomes as they relate to company's relationship with stakeholders (Caroll 1999; Gond \& Crane 2010; Wood 1991).

Normally, corporate social responsibility activities that lead to better social performance involve cost. The level of company's financial responsibility activities will typically influence firm's decision about social responsibility activities. Companies with strong financial performance can contribute to better social performance because companies with high financial performance had a better opportunity, in terms of financial resources to participate in social responsibilities activities (Mcguiree et al. 1988).Thus, less profitable firms may have low willingness to undertake socially responsible activities (Adams \& Hardwick 1998). Strong financial performance potentially results in availability of slack (financial)

\footnotetext{
${ }^{1} \mathrm{SR}$ is defined as a business commitment to contribute to sustainable economic development, working with employees, their families, local community and society to improve their quality of life (World Business Council for Sustainable Development).
} 
resources that provide the opportunity for companies to invest in activities that enhance in social performance. From slack resources theory point of view, availability of slack resources derived from company's profit is an important factor that influences social performance (Waddock \& Graves 1997; Preston O’Bannon 1997).

However, the finding from previous empirical study revealed mixed result. Study done by (Melo 2012; Fauzi $\&$ Idris 2009) revealed positive relationship between financial performance and social performance whereas study done by Aras et al. (2010), Fauzi et al. (2007), and McWilliam \& Siegel (2001) found insignificant relationship between financial and social performance. Thus, it indicates that, availability of slack resources would not necessary result in higher level of social performance. Without allocation of available slack in social performance activities, the level of social performance will not improve even though companies might have available slack from good financial performance.

The decision for allocation of slack resources to social performance is typically based on the discretion of people who have decision-making power in the organization (O'Bannon 1997). Institutional investors are among the people that have the highest decisionmaking power in company. Thus, they are expected to play role in allocating some portion of slack resources to other activities which related to social performance event or activities.

The previous studies supported the use of a moderator variable to overcome inconsistent finding in social performance and financial performance (Fauzi \& Idris 2010; Hull \& Rothenberg 2008; Orlitzky 2003). This is because the relationship between social performance and financial performance is not straightforward but involves a complex relationship (Roberto et al. 2007; Hull \& Rothenberg 2008). Previous studies proved that innovation, industry differentiation, business environment, strategy, structure, and control system moderate social performance and financial performance relationship (Hull \& Rothenberg 2008; Fauzi \& Idris 2010). These moderating variables focus on company strategic factor based on contingency approach.

Therefore, this study aims to investigate the relationship between SP and FP with director ownership as a moderator that will affect the relationship. Director that have a power to allocate the company resources, so if the director who held equity is expected have a power to influence the allocation available slack in social event. As the owner of the company is expected that support social event that lead to a better social performance. Social in further will give various benefit to a company such improve the reputation. This study predicts a positive relationship between FP and SP and the moderator variable (director ownership) will enhance that relationship. The study proposes that the availability of financial slack resources is an important factor that contributes to the SR spending and this will lead the better performance of SP. Slack resources represent potentially utilizable resources that can be redeployed to achieve companies' goal (Daniel et al. 2004).

This paper is organized as follows. The next section presents a discussion of the literature and hypothesis development followed methodology and findings. Finally conclusions and implications of the study are presented in the last section.

\section{Literature Review and Hypothesis Development}

\section{Corporate Financial Performance and Social Performance}

Past studies on the relationship between FP and SP performance are numerous and mainly focus on developed countries (see for examples, Aupprele et al., 1985; Waddock \& Graves 1997; Hull \& Rothenberg 2008; Mahoney \& Robert 2007; Callan \& Thomas, 2009). These studies focused on two main research issues; sign of direction and cause of direction. The sign of direction between SP and FP is found to be positive, negative, and neutral. The cause of direction question whether good SP would lead to better FP or good FP would lead to higher SP.

Conceptual explanations for negative, neutral and positive association between SP and FP are offered by Waddock and Grave (1997) and Preston and O'Bannon (1997). Their argument comes from neo-classical economics perspective, which stated that companies' involvement in social activities would incur additional costs that reduce profits and shareholder wealth. From the managerial opportunism hypothesis perspective, managers of a financially strong company would reduce expenditures on social activities so they can increase their personal compensation that tied to short term probability (Preston \& O'Bannon, 1997). Therefore, SP would negatively associate with FP (Waddock \& Grave 1997; Preston \& O’Bannon 1997). 
On the other hand, the positive association between SP and FP is argued based on stakeholder theory perspective which proposes the existence of conflict between the companies' explicit and implicit cost to stakeholder. This theory predicts that company that attempts to lower its implicit cost by being socially irresponsible would incur higher explicit cost resulting from being competitively disadvantage. Therefore, the relationship between SP and FP is negative. Argument for a neutral association advocates that there are so many intervening variables between SP and FP that there is no reason to expect a relationship to exist, except possibly by chance. Moreover, the measurement problems that have plagued SP research may mask any meaningful linkages (Ullman, 1985).

The second research issue relates to the direction of the relationship. Griffin and Mahon (1997) questioned whether good SP will lead better FP or good FP would lead to higher SP. Waddock and Graves (1997) and Dean (1998) proposed two theories to explain the direction of the relationship. Under the slack resources theory, FP comes first. Meaning, only financially strong company would have the necessary slack resources to engage in social activities. Therefore, FP would lead to better SP. On the other hand, good management theory proposes that SP would influence FP since socially responsible companies would get good support from stakeholders and would lead company to have stronger financial position through market mechanism (Waddock $\&$ Graves, 1997). Most of the studies that focused on the good management theory were carried out in developed countries.

This study employs slack resources theory to investigate the relationship between FP and SP in Malaysia. SR is still considered as a new agenda in Malaysian business environment. SP is seen as a cost incurred program so the availability of financial slack is important factor to motivate level of SP in Malaysia. Therefore, the direction andthe nature of the relationship between the variables are stated in the following hypothesis.

\section{HI. Financial performance is positively related to SP}

The influence of director ownership in the relationship between financial and social performance.

Agency theory proposed there is a positive relationship between managerial ownership and voluntary disclosure because top manager have the power to allocate resources among a broad range of stakeholders (Jensen
\& Meckling 1976). Normally the social action will increase firm value (Orlitzky et al. 2003). This can motivate the company director to engage in social activities. The increasing of firm value will attract the potential investor. As part of the shareholder, the director will influence the decision making to increase social event that benefits company performance. Furthermore SP performance can improve overall performance of company this also can motivate the directorto engage in social events.

Empirical findings also support the positive relationship between ownership by managers or directors and CSR engagement. There is a positive relationship between top management equity and social performance (Johnson \& Greening 1999). On the other hand, there is a negative relationship between managerial ownership and social rating (Won, Yong \& Martynov 2011; Xia \& Yuan 2007). So as conclusion, director ownership have an influence to company social performance. This will encourage the director in influencing the company decision of available slack in social activities. Therefore the following hypothesis is stated

H2. The level of director ownership is expected to strengthen the relationship between financial and performance and social performance.

\section{Methodology}

Sample of this study comprises of top 260 companies that listed on main market of Bursa Malaysia. Stratified random sampling was used to select sample. Data on financial and social performance was collected from the company annual reports for the year 2012. This approach is consistent with previous studies by Hackston and Milnes (1996) and Aras et al. (2010). In order to examine the moderating effect of director ownership in the FP and SP relationship, the interaction variable was used. The interaction variable is identified by multiplying Return on Equity and Financial Performance (ROE x Director Ownership). Relationship of moderator variable in the relationship will be proven when parameter for interaction is significant. 


\section{Measurement of Variables}

The dependent variable in this study, social performance (SP), is measured based on Global Reporting Initiatives $\left(\mathrm{GRI}^{2}\right)$ performance indicator. The indicator is considered to be a valid and suitable measure of CSP because it contains comprehensive measure of social and environmental performance (Sutantoputra, 2009). GRI performance indicator overcomes the onedimensional problem criticized by previous studies (Waddock \& Graves, 1997). This study adopts SR disclosure rating by Sutantoputra (2009) and Clarkson (1995), which has 87 total score of disclosure items. This rating system is developed based on GRI 2002 guidelines which categorized the score based on two categories: hard disclosures and soft disclosures. The SR score in this study was obtained by content analysed annual reports of selected sample companies.

The independent variables; financial performance is measured based on the last year's return on equity (ROE). It is because any fund available from previous year or slack resources, is believed can be allocated to SR spending for the current years. The method is consistent with majority of previous studies (Waddock \& Graves, 1997; McWilliam \& Siegel, 2001; Makni et al., 2008; Aras et al., 2010).

The control variables are size and leverage. These variables have been used in previous studies as factors that can influence both companies' performance and SP (Waddock \& Graves, 1997; William \& Siegel, 2001; Aras et al., 2010). Larger companies tend to receive more attention from the public and are under greater pressure to exhibit social responsibility (Cowen et al., 1987). Moreover larger companies are expected to have more slack resources to engage in social and environmental activities compared to small companies (Johnson \& Greening, 1999). Leverage is relevant as control variable because companies tend to engage in SR activities in order to reduce the perceived risk associated with debt instruments (Orlitzky \& Benjamin, 2001).

\footnotetext{
${ }^{2}$ The Global Reporting Initiative (GRI) is a network-based organization that produces a comprehensive sustainability reporting framework that is widely used around the world. GRI's Reporting Framework is developed through a consensus-seeking, multi-stakeholder process. Participants are drawn from global business, civil society, labour, academic and professional institutions. The Framework sets out the principles and Performance Indicators that organizations can use to measure and report their economic, environmental, and social performance.
}

\section{Research Model}

In order to examine the direct and interaction effect of both independent and moderator variables toward dependent variable, the following model is suggested. The basic model of CFP and CSP relationship is adapt from Waddock and Graves (1997).

$$
\begin{aligned}
& \mathrm{CSP}=\beta_{0}+\beta_{1} \mathrm{FP}+\beta_{2} \text { Dir.O/Ship } \\
& \beta_{3} \text { FP*Dir.O/Ship }+\beta_{4} \text { Size }+\beta_{5} \text { leverage }+€
\end{aligned}+
$$

\author{
Where: \\ CSP - Corporate social rating measured by \\ environmental and social disclosure rating \\ FP - Financial Performance measured by \\ return on equity (ROE) \\ Dir.O/Ship - Director ownership measured by \\ percentage of director ownership \\ Size - Total asset \\ Leverage - total debt / total asset
}

\section{Analysis and Findings}

Table 1 summarises the descriptive information of the variables in the study. The average of SP score is $9.5 \%$. This low SP score may be due to the employment of international standard measure, the GRI Index, in which not many Malaysian companies comply with the requirement (refer to Table 2). The average of the Director ownership is 32.06 is indicate that about $30 \%$ of company director held equity in the company. The average ROE is $7.13 \%$. The average scores for control variables are 19.94 for assets and 42.85 for leverage.

Table 1. Descriptive Statistics of Variables

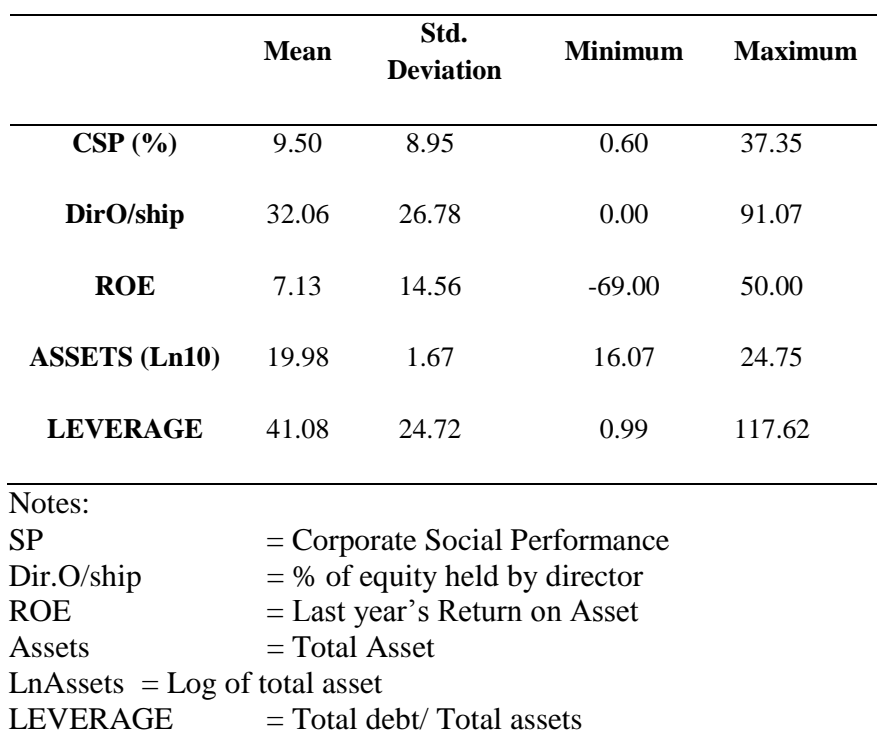


Table 2 represents the range of social performance score of selected companies for financial year ended financial year 2012.This SP score is for the social and environmental rating. The table shows that $78 \%$ of sample companies have SP score of $1 \%$ to $20 \%$ or less. Only $5 \%$ of overall company score more than 41 score rate. Majority of the company score in the range of 1 to 10. This indicates that majority of public listed companies have low level of social performance. Most o company from selected sample focus their social responsibility events on community.

Table 2. Corporate Social Performance Score

\begin{tabular}{|l|c|c|}
\hline Range CSP score rate & No of companies & Percentage \\
\hline $1-10$ & 138 & $53 \%$ \\
\hline $11-20$ & 66 & $25 \%$ \\
\hline $21-30$ & 26 & $10 \%$ \\
\hline $31-40$ & 16 & $7 \%$ \\
\hline $41-83$ & 14 & $5 \%$ \\
\hline Total & 260 & $100 \%$ \\
\hline
\end{tabular}

Before any multivariate analysis can be cad out, data were examined for extreme values and multicollinearity problems. Following Tabachnik and Fidell's2001 suggestion, we replaced the extreme values data with the nearest larger (smaller) scores in the distribution. Accordingly, we replaced three outliers which are ROE variable, LEVERAGE variable and SP variables

Pearson correlation analysis was carried out to detect multicollinearity problem among independent variables. Multicollinearity problem exists when correlation among variables exceed 0.9 (Tabachnik \& Fidell, 2001). Table 3 shows the Pearson correlation results. From correlation result no multicollinearity problem between variables in this study.
Table 3. Results of Pearson Correlation

\begin{tabular}{lcccccc}
\hline & SP & ROE & Dir.Oship & LnAsset & Leverage Interaction \\
\hline SP & 1 & & & & & \\
ROE & $0.231^{* *}$ & 1 & & & & \\
Dir.O/Ship & $-0.318^{* *}$ & $-0.830^{*}$ & 1 & & & \\
LnAsset & $0.432^{*}$ & $0.202^{* *}$ & $-0.252^{* *}$ & 1 & & \\
Leverage & $0.890^{*}$ & $-0.198^{* *}$ & $0.131^{* *}$ & $0.218^{* *}$ & 1 & \\
Interaction & 0.034 & $-0.706^{* *}$ & $0.245^{* *}$ & $0.083^{*}$ & $-0.201^{* *}$ & 1 \\
& & & & & & \\
\hline
\end{tabular}

Notes:

Interaction (ROE*Dir.O/Ship)

** Correlation is significant at 0.01 level (2-tailed).

* Correlation is significant at 0.05 level (2-tailed).

The result of regression analysis for a model is presented in Table 4. The results of model is significant with adjusted $\mathrm{R}$ square value of $25.70 \%$. The low explanation power is comparable to study by Waddock and Graves (1997) who have reported of $11 \%$ value of adjusted $R^{2}$.

The results in Model 1 show that last year's financial performance (ROE) influence the current year's social performance positively. The results give support for slack resource theory for the H1. The result indicates that financially strong companies would have the necessary slack resources to engage in social activities. This is consistent with finding from the previous studies (Waddock \& Grave, 1997; Fauzi et. Al., 2009; Orlitzky, 2003).

The results of the regression analysis also show the interaction variable (Dir.Oship*ROE) significantly and negatively influence the level of social performance of the company. Finding from this analysis provide a support to accept hypothesis 2. Director ownership has significant negative influence in FP and social performance relationship. Director ownership has significant negative relationship with social performance consistent with previous done by Won et al (2011) and Yuan (2007). It mean that the higher the equity hold by director the lower the percentage of company social performance. Justification for this finding it is because as owner of the company their goal is more toward shareholder maximization of wealth.

As a company shareholder the director may have an interest allocate the slack resources to the investment that give return in short time instead of invest in social responsibility in social responsibility activities. Normally social performance benefit can be observed in 
the long term period. However, finding from the previous study show there is positive relationship between director ownership and social performance (Johnson greening 1999: Orlitzky et al. 2003). This might due to a different perspective of board director toward social performance. In developed country social performance is a part of a company strategy to enhance financial performance so the board director is interested to spend slack resources in social activities. As developing country, board director in Malaysian company is not yet embrace social performance a company strategy, there are more focusing on the activities that contribute a return to a company. This scenario may contribute to the finding of negative relationship in this study.

The finding indicates that financially strong companies would lead companies to spend their excess resources in social related activities. Total asset as a control variable is significant in explaining independent variable. The results are inconsistent with results from prior studies (Waddock \& Graves, 1997; McWilliam \& Siegel, 2001; Aras et al., 2009) who suggest bigger companies are expected to have more slack resources to engage in social and environmental activities. Leverage as is not significant in explaining independent variables ant this is not consistent with previous finding where highly leverage companies tend to engage in CSR activities in order to reduce the perceived risk associated with debt instruments (Orlitzky \& Benjamin, 2001). In this study is found that the company leverage did not influence social performance level because the social performance in Malaysia is still at lower levels so it cannot reduce the risk associated with amount of debt

Table 4 Results of Regression Analysis

\begin{tabular}{lc}
\hline $\begin{array}{l}\text { Dependent Variable: } \\
\text { CSP }\end{array}$ & \multicolumn{1}{c}{ Model } \\
& Coefficient ( $\mathbf{t}$ value ) \\
\hline Constant & $(-0.7 .402)^{*}$ \\
\hline
\end{tabular}

Independent Variable :

ROE $\quad 0.221(4.661)^{* * * *}$

Moderator

Dir.O/Ship $\quad-0.185(-5.225) * * *$

Interaction variable:
ROE*Dir.O/ship

$-0.103(-02.130)^{* *}$

Control variable :
LnTA
$0.346(10.299) * * *$
Leverage
$0.013(0.383)$
F Value
53.55
R Square
0.257
Adjusted R Square
0.252

Notes:

CSP

ROE

Dir.O/ship

LnAssets

$$
=\text { Corporate Social Performance }
$$

$=$ Return on Equity,

LEVERAGE

$=$ Director ownership

$=$ Log of Total Asset

$=$ Total debt $/$ Total assets

\footnotetext{
* significant at $10 \%$

**significant at $5 \%$

$* * *$ significant at $1 \%$
}

\section{Conclusion and Research Implication}

This study aims to re-examine the relationship between corporate financial performance and social performance and the influence of director ownership on the relationship. The results show that financial performance is positively and significantly related to corporate social performance. This provides a support for slack resource theory that suggests financially strong companies have ability to invest in CSR activities that lead to better SP. In this study, the availability of slack resources leads companies to be more active in social related activities. The results of study provide an initial understanding of the influence of director ownership in FP and social performance relationship. However this study inherits several limitations. First, the rating process is based on researcher individual judgment, therefore its might open to different interpretation if the rates were to be calculated by different individuals. Secondly, this study only uses the annual report to gather information regarding companies' social activities. This is because the annual reports are valid and they serve as reliable sources of document to obtain information regarding the company. Since social responsibility is a form of voluntary disclosure this may be open to undisclosed certain social activities of the 
company. Nowadays, sustainability reporting is another comprehensive report that contains information regarding social and environmental activities but in Malaysia, the number of companies publishing this report is still scarce.

Future research can also be conducted the further investigation on the negative influence of director ownership in FP and SP relationship. To improve the generalization of the research finding, the future research should also consider expanding the sample in other markets listed in Bursa Malaysia, for example the ACE market. The ACE market replaces the MESDAQ market which functions as an alternative market that is open to various sizes of businesses and various economic sectors. Further research should consider alternative measure of CSP such balance score card (Panayiotou et al., 2009).

\section{References:}

Aras, G., Aybars, A. and Kutlu, O., (2010). Managing corporate performance investigating relationship between corporate social responsibility abd financial performance in emerging markets. International Journal of productivity and performance management, 59(3), pp. 229-254.

Aupperle, K.E. Carroll, A.B. and Hatfield, A.D., (1985). An empirical examination of relationship between Corporate Social Responsibility and Profitability.Academy Management Journal, 28 (2), pp. $479-486$.

Bouqet, B. andDeutch, Y., (2008). The impact of CSP on firm multinationality.Journal of Business Ethics, 80, pp. 755 - 767.

Callan, J. and Thomas, J., (2009). Corporate financial performance and corporate social performance: an update reinvestigation. Corporate Social Responsibility and Environmental Management, 16, pp. 61-78.

Cowen, S. S., Ferri, L. B., \& Parker, L. D., (1987). The impact of corporate characteristics on social responsibilitydisclosure: A typology and frequency-based analysis. Accounting Organizations and Society, 12(2), pp.111-122.

Daniel, F. Lohrke, F. Fornaciari C.F. and Turner.R.A., (2004). Slack resources and firm performance: a meta-analysis. Journal of Business Research, 57, pp. 565-574.

Dean, K.L., (1998). The Chicken and Egg Revisited: Ties Between Corporate Social Performance and
Financial Bottom Line. The Academy Management Executive, 2, pp. 99-100.

Dunn \&Sainty, (2009).The relationship among board of director characteristics, corporate social performance and corporate financial performance.International Journal of Finance, 5(4), pp. $1743-9132$.

Donaldson ,T., Preston, L.E., (1995). The stakeholder theory of the corporation: concepts, evidence and implications. Academy Management Review, 20, pp. 65-91.

Fauzi, H., (2009). The determinants of relationship of Corporate Social Performance and Financial Performance: Conceptual Framework. Issues in Social and Environmental Accounting, 2, pp. 233259.

Griffin, J.J. Mahon, J.F, (1997). The corporate social performance and financial performance debate: twenty-five years of incomparable research. Business \& Society, 36(2), pp. 5-31.

Hackston, D. and Milne, M.J, (1996). Some determinants of social and environmental disclosures in New Zealand companies.Accounting, Auditing \& Accountability Journal,9 (1), pp. 11-108.

Hull, C.E. and Rothenberg, S., (2008). Firm performance: the interactions of corporate social performance with innovation and industry differentiation. Strategic Management Journal, 29(7), pp. 781-789.

Ibrahim, N. A. and Angelidis, J. P. (1995).The corporate social responsiveness orientation of board members: Are there differences between inside and outside directors? Journal of Business Ethics, 14(5), pp. 405-410

Ingley, C.B., (2008). Company growth and board attitudes to corporate social responsibility.International Journal Business Governance and Ethics, 4(1), pp. 17-39.

Igalens, J., and Gond, J., (2005). Measuring Corporate Social Performance: A critical and empirical analysis of ARESE data. Journal of Business Ethics,56(2), pp. $131-148$.

Johnson, R.A. and Greening, D.W. (1999). The effects of corporate governance and institutional ownership types on corporate social performance.Academy of Management Journal, $42(5)$, pp. $564-576$.

Jones, T. (1991). Instrumental stakeholder theory: A synthesis of ethics and economics. Academy of Management Review, 24, pp. 404 - 307. 
Lu, W., Chau, K.W., Han, H., Pan, W. (2014). A critical view of empirical corporate social performance empirical study.Journal of Cleaner Product79:195 $-206$.

Mahoney, L. And Robert, R. (2007). Corporate social performance, financial performance and institutional ownership in Canadians firms. Accounting Forum. 31, pp. 233 - 253.

Mcwilliam, A., and Siegel, D., (2000). Corporate social responsibility and financial performance: correlation or missspecification?.Strategic Management Journal, 21, pp. 603-609.

Orlitzky, M. and Benjamin, J. D. (2001).Corporate Social Performance and Firm Risk: A MetaAnalytic Review, Business and Society, 40(4). pp. 369-396.

Orlitzky, M., Schmidt, F.L., Rynes, R.L., (2003). Corporate Social and Financial Performance: A Meta-Analysis. Organization studies, 24(3), pp. $95-113$.

Panayiotou, N. Aravossis, K. and Moschou, P., (2009). A new methodology approach for measuring corporate responsibility performance.Water Air SiolPollut: Focus, 9, pp. 129.138.

Peng, M. Li, Y. Xie, E. and Su, Z. (2010). CEO duality, organizational slack and firm performance in Cina.Asia Pacific Journal of Management, 27, pp. 611-624.

Surroca, J. Tribo, J. and Waddock, S. (2010). Corporate responsibility and financial performance: The role of intangible asset resources. Strategic Manegement Journal, 31, pp. 463-490.

Sutantoputra., (2009). Social disclosure rating system for assessing firms' CSR reports.Corporate Communication and International Journal, 14 (1), pp. 34 - 48.

Stanwick, P. and Stanwick, S. (2001). The determinants of corporate social performance: an empirical examination. American Business Review, pp. 8693.

Tabachinick, B.G. and Fidell, L.S., (2001). Using Multivariate Statistics, $4^{\text {th }}$ ed. Needham Heights: Allyh\& Bacon.

Ullman, A.H. (1985)., Data in search of theory: a critical examination of the relationships among social performance, social disclosure, and economic performance of US firms. Academy Management Review, 10(3), pp. 540-557.

The Star. 2011. 30 March.

Thompson, P., \&Zakaria, Z. (2004). Corporate social reporting in Malaysia.Journal of Corporate Citizenship, 13, pp. 125-126.
Waddock, S.A., and Graves, S.M. (1997). The Corporate Social Performance - Financial Performance Link.Strategic management Journal, 18(4), pp.203-319.

Wang, J. And Dewhirst, H.D. (1992). Boards of directors and stakeholder orientation, Journal of Business Ethic, 11(2), pp. 115-123. 